series of basalt-rocks with interbedded layers of palagonitic tuff, \&c. These rocks, so far as my observations go, exactly resemble those of the Færöe Islands. The basalt-rocks are chiefly anamesites, but some are true basalts, while others are dolerites. But in the areas traversed by me I saw none so coarse-grained or so highly porphyritic as those which occur so abundantly in Stromöe, Osteröe, and other islands of the Færöes. They form lofty plateaux, deeply gashed with gorges, and abruptly truncated, so as to present bold cliffs and precipices to the low grounds at their base, as in the case of the Esja near Reykjavik. Moreover, they appear to be developed chiefly in the maritime districts. Only a glance at these basaltic masses is needed to convince one that they are the mere fragments of what must once have been a most extensive plateau. The Esja, built up chiefly of comparatively horizontal beds of basalt, tuff, \&c., rises to a height of nearly 3000 feet above the low tracts at its base. Nor can there be any doubt that these beds formerly stretched far away in all directions, and that they have since been removed by the various agents of denudation from the broad undulating low grounds, over which they may still be traced, sometimes continuously for many miles, at other times in sporadic hills and rising grounds. which peer above the surface of the recent lavas by which they are surrounded. In short, the Miocene basalt-rocks of Iceland present precisely the same features as the similar rock-masses of the Færöes. Like the latter they probably formed at one time a wide elevated table-land, which has since been cut down and worn away-the lofty walls of the Esja, \&c., serving to give us some idea of the enormous erosion that has taken place. Now all this vast erosion had been effected before any of the later lavas, agglomerates, tuffs, \&c., in the south-west part of Iceland were erupted. In the region between Hafnarfjörd and Krísuvík the lavas have poured through old valleys in the Miocene rocks and spread themselves out over the highly denuded surface of the latter in the opener low grounds. In a word, it is evident that in the south-west part of Iceland a long interval separates the accumulation of the Miocene basalt-series from the eruption of the later volcanic rocks, and I incline to think that the same break in the continuity of volcanic action will be found to hold true for the rest of the island. I believe it will be found that there is no more connection between the display of volcanic activity in Miocene times and that of the present day in Iceland, than there appears to have been between the volcanic action which manifested itself in Scotland at such widely separated periods as those of the Lower Old Red Sandstone and the Carboniferous. Had there been more or less continuous volcanic activity in Iceland from Miocene times down to the present, we might well be surprised that the later volcanic masses are not much more considerable than they are. If we think of the time required for the removal by denudation of some 3000 feet of basalt-rocks, \&c., over thousands of square miles, we must be prepared to admit that the volcanic forces cannot have been continuously active. Either they have not been so, or the denuding agents have far surpassed them in energy.

There is another point which interested me. I found that the whole of the south-west region had been glaciated before the eruption of the later volcanic series. The Miocene basalts are everywhere ice-worn and abraded; roches moutonnées are well-marked, and in many places glacial ruts and striæ are conspicuous. Glacial gravels and coarse boulder-clay are likewise sprinkled over the surface of the low-lying tracts. Between Reykjavik and Hafnarfjörd the glaciation is distinctly from south-east to north-west, and could not have been the result of any mere local glacier. The whole wide tract has been overflowed by a general mer de glace. And if this be the case with that part of Iceland which now enjoys the mildest climate, we may be sure that the rest of the island must likewise have been enveloped in ice during the Glacial period. In the south-west region all the traces of glaciation ere strictly confined to the Miocene areas. Nothing of the kind is visible upon any of the later volcanic rocks. "These last have flowed over a glaciated surface, for the ice-worn Miocene basalts terminate abruptly at the margins of the wide sheets of black scoriaceous lava, as do also the driftaccumulations of glacial gravels and erratics, while now and again ice-worn knolls of basalt-rock may be seen rising up like islands in the midst of the later lava-fields. Everywhere the lavas and their associated agglomerates and tuffs show their original surfaces - the only changes which they have undergone being the result of subaërial weathering. In a word, all the post-Miocene eruptions of the southwest are of later date than the Glacial period. It would be interesting to ascertain whether the same is the case throughout Iceland. As there is every probability that the great break in the continuity of volcanic action, of which I have spoken, is not confined to the south-west, but may hold true of the whole island, it seems not unlikely that the conclusions I have formed as to the postGlacial age of the later volcanic series of the south-west will also be extended to the same series in other districts. In other words, we may yet be compelled to admit that the oldest eruptions of Hecla and her sisters are not only of vastly more recent age than any of the Miocene basaltrocks, but belong to one of the latest epochs of which geology takes cognisance.

JAMES GEIKIE

\section{THE EVOLUTION OF THE PALAEOZOIC VEGETATION}

SOME statements made in Mr. Starkie Gardner's abstract (NATURE, vol. xxiv. p. 558) of the recent work of Saporta and Marion "On the Evolution of the Cryptogams" are so opposed to conclusions at which I have arrived that I can scarcely allow them to pass unchallenged, lest by doing so it may be inferred that I no longer oppose the French school of Carboniferous palæo-botanists on several vital points connected with the interpretation of the Carboniferous flora. But before doing so I may venture to suggest a doubt whether the time has yet arrived for making the attempt to trace the lines of descent of the Palæozoic flora. It is true that much has been done of late years to extend our knowledge of that flora, but perhaps at the same period our knowledge of the extent of our ignorance has, pari passu, been equally enlarged. We now possess accurate information respecting the structure of many well-known plants, but we have also obtained glimpses of the existence of many obscure but very important organisms which represent factors that cannot be left out of consideration in dealing with the problem of their evolution. Besides this, opinions of experts are widely divergent on some very important questions of interpretation affecting the relationship of conspicuous plants whose organisation is understood. So long as experienced palæontologists are disagreed on the relations of the Calamites to the Calamodendra, and of the Lepidodendra to the Sigillariæ, a scheme of evolution explaining the development of the Carboniferous flora can scarcely be possible. The French school of botanists still believe that what they call Calamites are Equisetaceous Cryptogams, whilst the Calamodendra are Gymnospermous Phanerogams. In like manner they believe the Lepidodendra to be Cryptogams, and as such to be devoid of all exogenous growths in the exterior of their stems, whilst they regard all the Lepidodendroid stems that possess such growths as Sigillariæ, and relegate them also to the Gymnospermic section of the vegetable kingdom. I am more than ever convinced that these views cannot be sustained, and I think that my memoirs on these subjects, especially Parts IX. and XI., 
contain a sufficiently abundant array of detailed facts to justify the conclusions at which I have arrived.

But even were this not the case, there are other important considerations that cannot be overlooked. As I have already hinted, we have become acquainted with a large number of curious organisms, many of which are unmis. takably reproductive, but respecting the botanical affinities of which we are as yet entirely ignorant. New forms present themselves in a more rapid ratio than discoveries are made of the true character of older ones. Yet many of these objects are so remarkable that they must have constituted very important links in the chain of Palæozoic life; and until we learn more about them than we at present know, we cannot possibly assign to them their true place in that chain; whilst their omission must leave serious gaps in the succession.

But our difficulties do not end here. All the objects to which I have just referred have been discovered but recently. Ten years ago we knew nothing of their existence, and new forms are still being added to our cabinets. The old fossiliferous shales and sandstones revealed no traces of them. We only found them when the microscope came to be applied to the calciferous nodules of Oldham and Halifax. Our first supply of special types was derived from the former locality. The examination of the Halifax nodules revealed the existence of several new forms, though obtained from the same geological horizon and from localities but a few miles apart. Arran and Burntisland have, in like manner, contributed types wholly unknown in Yorkshire and Lancashire, and the French localities of Autun and St. Étienne (where also are found Carboniferous plants of which all the structure is preserved) have each their own characteristic forms. ${ }^{1}$ We thus learn that so far as these six special localities are concerned, whilst certain common features characterise their floras, each locality has, as in living floras, genera or species peculiar to itself. Now we chiefly know the full extent of the localisation of these six Carboniferous floras from their accidental preservation in calcified or siliceous deposits, and not from the revelations of the ordinary fossiliferous shales and sandstones. But we cannot suppose that the six localities enumerated are the only ones that possessed floras peculiar to themselves. Does not common reasoning justify the suggestion that all Carboniferous plant-bearing localities would exhibit similar features, had their fossils been preserved as they are at Halifax or at St. Étienne? If so, seeing how widely Carboniferous deposits are diffused throughout the world, what myriads of minute, but phytogenetically important forms of plant-life must have existed of which we are absolutely ignorant-an ignorance that can only be diminished by the discovery of other localities as productive as the six that $I$ have enumerated.

But even were we perfectly acquainted with the Carboniferous flora, we should not be much nearer the end. Beyond the fact, established by Dr. Dawson, that in the Devonian age a flora existed almost, if not wholly, as rich as the Carboniferous one, a flora in which Gymnosperms existed with as high an organisation as characterised the similar Carboniferous types, what do we know respecting the minuter forms of this flora, which correspond to those which I have described from the Coal-measures? But can it be doubted that such objects must have existed in abundance? Still less can it be supposed that so rich and highly organised a flora as that of the Devonian age first sprang into existence during that age. That flcra must have been preceded by one rich in types of a lower terrestrial vegetation than is represented by the ferns-

I I believe that this fact partly explains the unwillingness of the French palzontologists to accept our English views as to the close affinities existing between the Lepidodendra and the Sigillariz. The peculiar Diploxyloid forms of Lepidodendron, i.e. those which possess the outer exngen us zone which the French botanists regard as characteristic of, a Sigillarian stem, appear to be absent from the beds of Autun and St. Etienne, as they are rare in Canada and the United States. In Great Britain, on the other hand, they constitute, with several variations of specific details, our prevailing type. the Lycopods and the Dadoxylons of the Devonian beds of North America. But what do we know of this earlier flora? Almost nothing. The remains of pre-Devonian plants now known are so obscure that little reliance can be placed upon them. Eophyton is rejected from the vegetable kingdom by Nathorst, and most of the other so-called Fucoids of the Palæozoic strata are of almost equally dubious nature. Where more definite forms of what may probably be Marine Algæ do occur they come too late in time to avail in the construction of the Palæozoic pedigree. Even the Liassic Chondraites bellensis of the Lias cannot be depended upon with absolute certainty. It is only when we reach the Tertiary age that we find the Delesseriæ and Halymenites in shapes that leave little room for doubting their true nature. Yet our French friends trust to these dubious objects as being real Fucoids, and as such, the ancestral predecessors of the higher Cryptogams of the Devonian and Carboniferous ages. So long as this ignorance and uncertainty remain, it seems to me that we cannot construct, with any degree of probability, the genealogical tree of Palæozoic plant life.

As to the many detailed conclusions arrived at by MM. Saporta and Marion, I will only refer to two or three statements in addition to the more important ones to which I have already called attention. Thus Mr. Gardner's abstract states that "eight still existing Diatoms have been discovered in British Coal." I thought that I had thoroughly exploded that fallacy in my Memoir, Part X. MM. Saporta and Marion conclude that Asterophyllites was a floating or procumbent plant allied to the Equisetaceæ, thus following $M$. Renault in separating it from Sphenophyllum, which the authors believe to be a Rhizocarp allied to Salvinia. I see no ground whatever for these conclusions. They further consider that some of his Calamariæ (Equisetaceæ) were heterosporous. They arrive at this conclusion from my discovery that Calamostachys Binneana, which I believe to be a fruit of an Asterophyllitean plant, was a heterosporous Strobilus; but I wholly demur to the idea that either the plant or the fruit was Equisetaceous.

For the reasons above given, I doubt whether even my valued friend the Marquess Saporta, highly accomplished as I know him to be, will be able to "make clear the precise lines through which the evolution of the one from the other [i.e. the Phanerogams from the Cryptogams] has been accomplished.'

Owens College, Manchester, October i4

\section{THE INTERNATIONAL EXHIBITION AND CONGRESS OF ELECTRICITY AT PARIS ${ }^{1}$}

\section{V.}

THE labours of the jury are now finished, and the distribution of medals took place on October 21 at the Conservatoire des Arts et Métiers. It is understood that they have been somewhat liberal in their distribution of honours, and have endeavoured to make things pleasant all round. Indeed the time allotted to them for investigation being postponed for a week at the beginning, and afterwards cut short by a week at the end, was quite insufficient to settle the burning question which is the best of all the electric lights.

The diploma of honour (diplôme d'honneur), which is the highest award of all, has been voted to Dr. Werner Siemens, Sir William Thomson, Mr. Edison, M. Gramme, Prof. Graham Bell, Prof. Hughes, Prof. Pacinotti, Prof. Bjerknes, M. Gaston Planté, M. Baudot, and M. Marcel Deprez, the last-named being the inventor of a system of distribution of electricity which has found much favour in Paris. M. Baudot is the inventor of a multiple printingtelegraph. The Exhibition has been announced to close on November 15 , but there is some talk of a later date.

$$
2 \text { Continued from p. } 58 \mathrm{~g}
$$

